\title{
Soil physical properties, nitrogen uptake and grain quality of maize (Zea mays L.) as affected by tillage systems and nitrogen application
}

\author{
Allah Wasaya, ${ }^{1}$ Muhammad Tahir, ${ }^{2}$ Tauqeer Ahmad Yasir, ${ }^{1}$ Muhammad Akram, ${ }^{3}$ \\ Omer Farooq, ${ }^{4}$ Naeem Sarwar ${ }^{4}$ \\ ${ }^{1}$ College of Agriculture, Bahauddin Zakariya University, Bahadur Sub-Campus Layyah, Pakistan; \\ ${ }^{2}$ Department of Agronomy, University of Agriculture, Faisalabad, Pakistan; ${ }^{3}$ Department of Environmental \\ Sciences, COMSATS University, Islamabad, Pakistan; ${ }^{4}$ Department of Agronomy, Bahauddin Zakariya \\ University, Multan, Pakistan
}

\begin{abstract}
Soil compaction is a global issue pertaining to agricultural lands. The frequent use of farm machinery and field operations at the same depth are the major causes of soil compaction. The gradual increase in soil compaction deteriorates maize grain quality due to reduced nitrogen $(\mathrm{N})$ uptake. Quality food production by reducing soil compaction is the need of time, which can be achieved through deep tillage and $\mathrm{N}$ management. In this study, three tillage systems viz. conventional tillage (using cultivator), tillage with mould board plough +2 -cultivations (MBP), and tillage with chisel plough +2 -cultivations $(\mathrm{CP})$; and three nitrogen levels viz. 100,150 and $200 \mathrm{~kg} \mathrm{ha}^{-1}$ were used to evaluate their effect on soil properties, $\mathrm{N}$ uptake and grain quality in maize. Lower bulk density $\left(1.41 \mathrm{Mg} \mathrm{m}^{-3}\right)$, higher total porosity $\left(0.47 \mathrm{~m}^{3}\right.$ $\mathrm{m}^{-3}$ ) and higher nitrogen uptake (96.01 $\mathrm{kg} \mathrm{ha}^{-1}$ ) was recorded under chisel plough (CP) compared with other tillage systems. Different $\mathrm{N}$ levels had significant effect on grain and total $\mathrm{N}$ uptake and grain quality, while soil properties remains unaffected. Higher $\mathrm{N}$ uptake was recorded with $200 \mathrm{~kg} \mathrm{ha}^{-1} \mathrm{~N}$ application than other treatments. Similarly, $8.51 \%$ and $8.57 \%$ more grain protein contents were recorded with $200 \mathrm{~kg} \mathrm{ha}^{-1} \mathrm{~N}$ during first and second
\end{abstract}

Correspondence: Allah Wasaya, College of Agriculture, Bahauddin Zakariya University, Bahadur Sub-Campus Layyah, 31200 Pakistan. Tel.: +92.03006765024.

E-mail: wasayauaf@gmail.com

Key words: Bulk density; grain quality; maize; nitrogen uptake; total porosity; tillage systems.

Acknowledgements: the authors are grateful to University of Agriculture Faisalabad, Pakistan for providing funds for completion of this research project as a part of Ph.D. thesis.

Received for publication: 15 January 2018.

Revision received: 20 August 2018.

Accepted for publication: 27 August 2018.

CCopyright A. Wasaya et al., 2018

Licensee PAGEPress, Italy

Italian Journal of Agronomy 2018; 13:1197

doi:10.4081/ija.2018.1197

This article is distributed under the terms of the Creative Commons Attribution Noncommercial License (by-nc 4.0) which permits any noncommercial use, distribution, and reproduction in any medium, provided the original author(s) and source are credited. year respectively. Unlike grain protein, starch and oil contents were negatively affected by $\mathrm{N}$ application being higher starch (71.7\%) and oil contents (3.41\%) with less $\mathrm{N}$ supply (100 $\left.\mathrm{kg} \mathrm{ha}^{-1}\right)$. However, interaction effect of tillage and nitrogen levels was found non-significant for all studied parameters except for oil contents. Higher oil contents were recorded with MBP along with 100 $\mathrm{kg} \mathrm{ha}^{-1} \mathrm{~N}$ application. Overall study indicated that deep ploughing with CP is important for maize to explore more soil area for nutrient uptake and $\mathrm{N}$ is also important for improving grain quality especially protein contents an important food constituent.

\section{Introduction}

Continuous cultivation of agricultural soils with same implement and at same depth creates hard pan (Hamza and Anderson, 2005; Wasaya et al., 2011). The existence of hard pan in soil has negative impact on soil bulk density and porosity leading to increased root penetration resistance and poor nutrient uptake, which directly or indirectly affects the crop yield (Ishaq et al., 2003; Shahzad et al., 2016a, 2016b). Moreover, different tillage operations also affect the soil compactness or looseness, as growing crops by no-tillage for many years adversely affects crop growth by limiting nutrients availability due to hard subsoil layer (Mead and Chan, 1988). Existence of soil compaction decreases uptake of $\mathrm{N}(11-15 \%), \mathrm{K}(5-10 \%)$ and $\mathrm{P}(11-15 \%)$ and yield reduction of wheat (Ishaq et al., 2003).

Deep tillage is the most effective practice to reduce compaction (Daniells, 2012) and has a significant impact on soil physical properties such as moisture contents, bulk density, penetration resistance, soil porosity and aeration (Liu et al., 2016; Shahzad et $a l ., 2016 b)$. Tilling the soil at more depth improves soil physical properties and hence leads to high crop yield (Ji et al., 2013). Moreover, subsoiling also improves the soil porosity and enhances root proliferation at deeper depth for the uptake of nutrients and moisture (Ji et al., 2013). Similarly, soil penetration resistance (Wang et al., 2009) and soil cone index (Wang et al., 2009) also decreased with increasing tillage intensity. Soil disturbance usually enhance $\mathrm{N}$ availability for plant use by improving soil aeration and mineralization of organic N (Dinnes et al., 2002). Soil compaction can be removed by increasing porosity or decreasing bulk density of soil (Hamza and Anderson, 2005), which is possible through sub-soiling up to $30 \mathrm{~cm}$ depth. It may increase aeration and soil hydraulic conductivity more than double and enhances soil porosity up to $27 \%$ (Drewry et al., 2000). Similarly, soil loosening by tilling also improves grain yield (Schmidt et al., 1994; Wasaya et al., 2017a) and biomass production (Wasaya et al., 2012) by improving water infiltration rate and root proliferation 
(Wang et al., 2015). On the other hand, deep tillage also has some negative effects on soil structure. It lowers soil organic matter due to higher decomposition rate because soil inversion generates more soil aeration and favours microbial activity (Six et al., 2000).

Nitrogen is a major nutrient for plants, which limits their growth if not applied in adequate amount. Higher rather than adequate $\mathrm{N}$ level in the soil negatively affects the crop growth (Oscar and Tollenaar, 2006). Maize (Zea mays L.) shows positive response to $\mathrm{N}$ application depending upon different climatic and edaphic factors such as nutrient status, soil characteristic and the nutrient response of the cultivated varieties (Nagy, 1997) and produce high dry matter (Greef et al., 1999). Its application to maize resulted in increased grain yield $(24 \%)$ and biomass production (22\%) (Amanullah et al., 2009) due to improvement in yield components (Sharifi and Taghizadeh, 2009). In addition to yield improvement, $\mathrm{N}$ increments also have positive impact on grain quality. Increasing $\mathrm{N}$ application in different cropping environments leads to increase in grain protein while decrease in grain oil and starch contents in maize (Singh et al., 2004; Miao et al., 2006). Interaction effect of tillage and nitrogen application on maize with different $\mathrm{N}$ sources (commercial $\mathrm{N}+$ liquid manure) found nonsignificant (Mensah and Al-Kaisi, 2006). Similarly, a non-significant interaction effect of tillage and split application of $\mathrm{N}$ was also observed for grain yield and related traits in maize (Wasaya et al., $2017 b$ ). Contrary to this a wheat yield was strongly affected by the season, tillage and $\mathrm{N}$ rate interactions (Feng et al., 2014). However, in another study it has a significant effect on improving soil $\mathrm{N}$ and grain yield (Ahmad et al., 2009).

Framers of semi-arid irrigated regions usually grow maize fol- lowing conventional tillage practices and apply under dose of $\mathrm{N}$ due to unavailability and high cost of fertilizers and tillage implements. Ploughing the field in a conventional way leads to creation of hard pan, which could be a possible cause of less $\mathrm{N}$ uptake due to poor root penetration. Although some researcher has studied the effect of tillage and $\mathrm{N}$ management as individual factor in maize but their interaction effect under semi-arid irrigated conditions is lacking. Therefore, a two-year field study was conducted to evaluate the effect of different tillage systems and $\mathrm{N}$ levels on soil physical properties, $\mathrm{N}$ uptake and grain quality in maize under semiarid irrigated conditions.

\section{Materials and methods}

\section{Experimental site description}

This study was conducted during summer season of 2008 and 2009 at Agronomic Research Farm, University of Agriculture, Faisalabad $\left(73^{\circ} \mathrm{E}, 31^{\circ} \mathrm{N}\right.$ and $135 \mathrm{~m}$ above sea level), Pakistan. Soil of the experimental field was sandy clay loam, which contained 58, 20.2 and $21.8 \%$ sand, silt and clay respectively. The experimental soil was also analysed for its chemical properties including EC $1.46 \mathrm{ds} \mathrm{m}^{-1}, \mathrm{pH} 7.9$, organic matter $0.70 \%$, organic carbon $0.41 \%$, total N $0.038 \%$, available P 6.4 ppm and available $\mathrm{K} 117 \mathrm{ppm}$. The crop was sown under semi-arid climatic conditions and irrigated with canal water. The weather data for both study years is given in Figure 1.

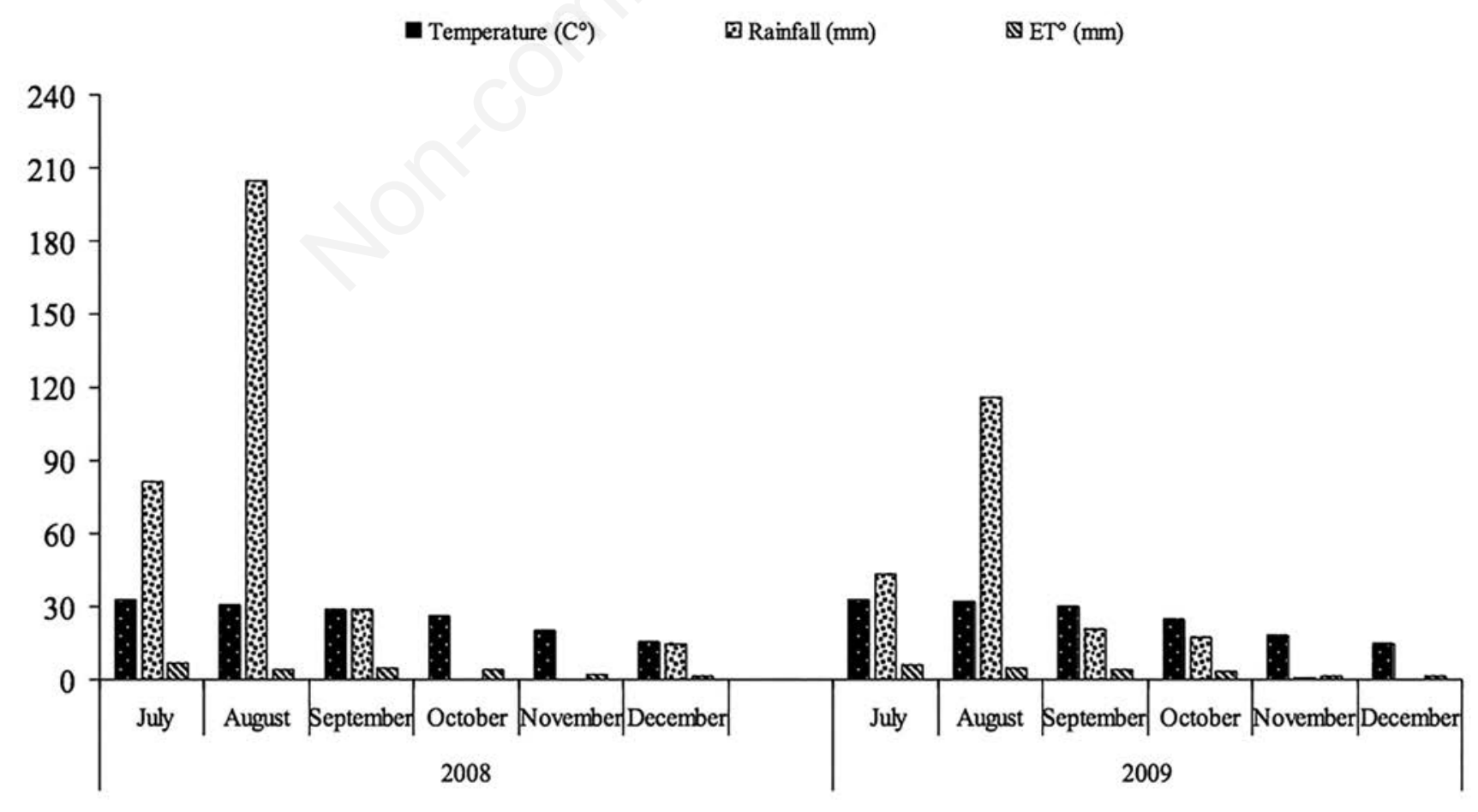

Figure 1. Weather data for study period for 2008 and 2009. 


\section{Experimental details}

The study was consisted of three tillage systems viz. conventional tillage (CT) (using cultivator), tillage with mould board plough (MBP), and tillage with chisel plough (CP) each followed by two cultivations and three nitrogen $(\mathrm{N})$ levels viz. 100, 150 and $200 \mathrm{~kg} \mathrm{ha}^{-1}$. In CT, soil was cultivated twice with tractor mounted cultivator followed by planking. In MBP, soil was cultivated with mould board plough upto $30 \mathrm{~cm}$ depth followed by 2-cultivations with tractor mounted cultivator, and one planking. In CP soil was cultivated twice with chisel plough upto $40 \mathrm{~cm}$ depth followed by cultivator (2-cultivations) and one planking. Three different $\mathrm{N}$ levels 100,150 and $200 \mathrm{~kg} \mathrm{ha}^{-1}$ were applied to maize crop. Three different levels were chosen to investigate the impact of low (farmer practice), medium (recommended) and high rates of $\mathrm{N}$ levels on maize yield. The experiment was carried out in a split plot design keeping tillage systems in main and $\mathrm{N}$ levels in sub-plots. All the treatments were replicated thrice with net plot size of $4.5 \times 10 \mathrm{~m}$.

\section{Crop husbandry}

A pre-soaking irrigation of $10 \mathrm{~cm}$ was applied to experimental field before maize sowing and final seedbed was prepared after six days of irrigation when soil moisture reached at workable condition. Seedbed was prepared according to treatments and maize hybrid pioneer-31R88 was sown with the help of dibbler using 25 $\mathrm{kg} \mathrm{ha}^{-1}$ seed rate, at line-line distance of $75 \mathrm{~cm}$ and plant-plant distance of $20 \mathrm{~cm}$ on August 07, 2008 and August 01, 2009. Two seeds per hill were planted manually and then thinning was done at 3-leaf stage by maintaining one plant per hill. Phosphorous $(\mathrm{P})$ and potassium $(\mathrm{K})$ were applied at $100 \mathrm{~kg} \mathrm{ha}^{-1}$ each along with $\mathrm{N}$ as per treatments. Whole $\mathrm{P}$ and $\mathrm{K}$ were broadcasted and mixed with soil through ploughing at sowing time, while $\mathrm{N}$ was applied in three splits. Half of the total $\mathrm{N}$ according to each treatment was broadcasted and mixed with soil through ploughing at sowing time and remaining half was side-dressed in two splits i.e. at 5-leaf stage (V5) and at tasseling (VT). Nitrogen was applied using urea while $\mathrm{P}$ and $\mathrm{K}$ were applied using single super phosphate (SSP) and sulphate of potash, respectively. Crop was irrigated with canal water through surface irrigation method when needed. Overall five irrigations each of $7.5 \mathrm{~cm}$ depth were applied to mature the crop. All other agronomic practices except specific treatments were kept uniform for all experimental units. Appropriate plant protection measures were used to keep the crop free from diseases and insect attack. Crop was harvested at physiological maturity.

\section{Observations recorded}

\section{Soil properties}

Three soil samples were randomly collected from each experimental unit between the rows with the help of soil core sampler immediately after maize harvesting to analyse the soil properties such as soil bulk density, soil total porosity and soil organic matter. The samples were taken from 2 different depths, $0-15 \mathrm{~cm}$ and $15-$ $30 \mathrm{~cm}$, mixed and then oven dried at $105^{\circ} \mathrm{C}$ for $48 \mathrm{~h}$. To collect the soil samples soil cores of $0.08 \mathrm{~m}$ height and $0.05 \mathrm{~m}$ diameter were used (Blake and Hartge, 1986). Bulk density was estimated as a ratio of soil mass to soil volume. The same soil samples were then used for calculating particle density as a ratio of dry soil mass to volume (Blake and Hartge, 1986). The total porosity of soil was estimated following Vomocil (1965).

\section{Nitrogen indices}

Different $\mathrm{N}$ indices like total $\mathrm{N}$ uptake $\left(\mathrm{kg} \mathrm{ha}^{-1}\right)$, grain $\mathrm{N}$ uptake $\left(\mathrm{kg} \mathrm{ha}^{-1}\right), \mathrm{N}$ utilization efficiency (NUtE) $\left(\mathrm{kg} \mathrm{kg}^{-1}\right)$ and $\mathrm{N}$ harvest index (NHI) (\%) were calculated using following equations.

$$
\text { Total } \mathrm{N} \text { uptake }=\mathrm{DM}(\text { above ground }) \times \frac{\mathrm{N}(\mathrm{DM})}{100}
$$

where DM indicates above ground dry matter and N (DM) indicates the $\mathrm{N}$ concentration in the above ground dry matter.

$$
\text { Grain } \mathrm{N} \text { uptake }=\text { grain yield } \times \frac{\text { grain } \mathrm{N}}{100}
$$

where grain $\mathrm{N}$ indicates the $\mathrm{N}$ concentration in maize grain.

Nitrogen utilization efficiency was recorded using the formula as proposed by (Fiez et al., 1995):

$$
\mathrm{NUtE}=\frac{\text { grain yield }}{\text { total } \mathrm{N} \text { uptake }}
$$

where NUtE represents $\mathrm{N}$ utilization efficiency in $\mathrm{kg} \mathrm{kg}^{-1}$ :

$$
\mathrm{NHI}=\frac{\text { grain } \mathrm{N} \text { uptake }}{\text { total } \mathrm{N} \text { uptake }} \times 100
$$

where NHI represents $\mathrm{N}$ harvest index (\%).

\section{Grain quality}

For estimation of protein contents the grain samples were oven dried at $70^{\circ} \mathrm{C}$ for $24 \mathrm{~h}$. After drying, the samples were grinded with mechanical grinding machine and $\mathrm{N}$ content in maize grain was estimated using micro-Kjeldahl method (Anonymous, 1990). Then protein contents were computed using following formula:

Protein content $(\%)=\mathrm{N}$ concentarion $\times 6.25$

Oil contents in maize grain were estimated by Soxhlet method as proposed by Low (1990) and starch contents were estimated by Gluco-amylase method (Anonymous, 1990).

\section{Statistical analysis}

Data collected through standard procedures were statistically analysed using statistical package MSTAT-C (Freed and Scott, 1986). Analysis of variance technique (ANOVA) and LSD test at $5 \%$ probability level was used to compare the differences among treatment's means (Steel et al., 1997). Standard error was calculated using Microsoft excel software program while, figures were drawn using sigma plot software.

\section{Results}

The results indicated that bulk density and total porosity of soil were significantly affected by different tillage systems. Lower soil bulk density and higher total porosity were observed under chisel ploughed plots. Soil carbon remained unaffected with either of the tillage systems during both study years (Table 1). Different $\mathrm{N}$ levels had non-significant effect on all three soil properties during both study years (Table 1). Similarly, the interaction effect between tillage systems and $\mathrm{N}$ levels for aforementioned soil characters 
were also found non-significant (Table 1).

Different tillage systems and $\mathrm{N}$ levels had significant effect on grain and total $\mathrm{N}$ and non-significant effect was found on stover $\mathrm{N}$ uptake during both study years. Nitrogen utilization efficiency (NUtE) and $\mathrm{N}$ harvest index (NHI) remained unaffected during first and significantly affected by tillage systems only during second year (Table 2). Higher grain and total $\mathrm{N}$ uptake was recorded in maize grown under chisel plough and was at par with conventional tillage systems while minimum was recorded in mould board ploughed plots during both years (Table 2). Among N levels, higher stover, grain and total $\mathrm{N}$ uptake was recorded in maize applied with $200 \mathrm{~kg}$ $\mathrm{ha}^{-1} \mathrm{~N}$ compared with other $\mathrm{N}$ levels during both years of study (Table 2). However, the interaction effect for all $\mathrm{N}$ indices remained unaffected during both study years (Tables 3-5).

Different tillage systems and $\mathrm{N}$ levels had also significant effect on oil contents and was non-significant effect on protein and starch contents during both years (Table 3). However, N application had significant effect on protein, oil and starch contents and their interaction effect was non-significant except for oil content which was found significant during both years (Table 3 ). The higher oil contents were recorded in maize grown under conventional tillage compared with other treatments. However, minimum oil contents were recorded in maize grown under chisel plough (Table 3). Regarding N levels, higher protein contents and lower oil and starch contents were recorded in maize grown with $200 \mathrm{~kg} \mathrm{ha}^{-1} \mathrm{~N}$ application while lower protein and higher oil and starch contents were recorded in maize grown under $100 \mathrm{~kg} \mathrm{ha}^{-1} \mathrm{~N}$ application (Table 3). Regarding interaction effect, higher oil contents were recorded in maize grown under mould board plough by applying $100 \mathrm{~kg} \mathrm{ha}^{-1} \mathrm{~N}$ compared with all other treatment combinations during both years of study (Figure 2).

Table 1. Effect of different tillage systems and nitrogen levels on soil properties.

\begin{tabular}{|c|c|c|c|c|c|}
\hline Year & & & $\begin{array}{l}\text { Soil bulk density } \\
\left(\mathrm{Mg} \mathrm{m}^{-3}\right)\end{array}$ & $\begin{array}{l}\text { Soil porosity } \\
\left(\mathrm{m}^{3} \mathrm{~m}^{-3}\right)\end{array}$ & $\begin{array}{l}\text { Soil C } \\
\left(\mathrm{g} \mathrm{kg}^{-1}\right)\end{array}$ \\
\hline \multirow[t]{3}{*}{2008} & \multirow[t]{4}{*}{ Tillage (T) } & $\mathrm{CT}$ & $1.46^{\mathrm{ab}} \pm 0.03$ & $0.45^{\mathrm{b}} \pm 0.01$ & $3.16 \pm 0.13$ \\
\hline & & MBP & $1.49^{\mathrm{a}} \pm 0.03$ & $0.44^{\mathrm{b}} \pm 0.01$ & $2.96 \pm 0.18$ \\
\hline & & $\mathrm{CP}$ & $1.41^{\mathrm{b}} \pm 0.02$ & $0.47 \mathrm{a} \pm 0.01$ & $3.21 \pm 0.23$ \\
\hline \multirow[t]{4}{*}{ LSD (0.05) } & & & 0.06 & 0.02 & NS \\
\hline & \multirow[t]{5}{*}{ Nitrogen $(\mathrm{N})$} & $\mathrm{N}_{1}$ & $1.45 \pm 0.03$ & $0.45 \pm 0.01$ & $3.00 \pm 0.18$ \\
\hline & & $\mathrm{N}_{2}$ & $1.45 \pm 0.03$ & $0.46 \pm 0.01$ & $3.05 \pm 0.13$ \\
\hline & & $\mathrm{N}_{3}$ & $1.46 \pm 0.03$ & $0.45 \pm 0.01$ & $3.28 \pm 0.22$ \\
\hline \multirow[t]{2}{*}{ LSD (0.05) } & & & NS & NS & NS \\
\hline & & $\mathrm{T} \times \mathrm{N}$ & NS & NS & NS \\
\hline \multirow[t]{3}{*}{2009} & \multirow[t]{4}{*}{ Tillage (T) } & CT & $1.44^{\mathrm{ab}} \pm 0.02$ & $0.46^{\mathrm{ab}} \pm 0.01$ & $2.81 \pm 0.12$ \\
\hline & & MBP & $1.47^{\mathrm{a}} \pm 0.03$ & $0.45^{b} \pm 0.01$ & $2.77 \pm 0.10$ \\
\hline & & $\mathrm{CP}$ & $1.39^{\mathrm{b}} \pm 0.02$ & $0.48^{\mathrm{a}} \pm 0.01$ & $3.00 \pm 0.12$ \\
\hline \multirow[t]{4}{*}{ LSD (0.05) } & & & 0.05 & 0.03 & NS \\
\hline & \multirow[t]{5}{*}{ Nitrogen $(\mathrm{N})$} & $\mathrm{N}_{1}$ & $1.43 \pm 0.03$ & $0.46 \pm 0.01$ & $2.82 \pm 0.12$ \\
\hline & & $\mathrm{N}_{2}$ & $1.43 \pm 0.03$ & $0.46 \pm 0.01$ & $2.86 \pm 0.14$ \\
\hline & & $\mathrm{N}_{3}$ & $1.44 \pm 0.03$ & $0.46 \pm 0.01$ & $2.91 \pm 0.13$ \\
\hline \multirow[t]{2}{*}{ LSD (0.05) } & & & NS & NS & NS \\
\hline & & $\mathrm{T} \times \mathrm{N}$ & NS & NS & NS \\
\hline
\end{tabular}

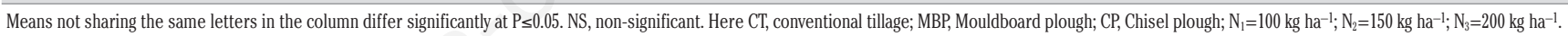

Table 2. Effect of different tillage systems and nitrogen levels on nitrogen indices in maize.

\begin{tabular}{|c|c|c|c|c|c|c|c|}
\hline Year & & & $\begin{array}{l}\text { Stover } \mathrm{N} \text { uptake } \\
\left(\mathrm{kg} \mathrm{ha}^{-1}\right)\end{array}$ & $\begin{array}{l}\text { Grain N uptake } \\
\left(\mathrm{kg} \mathrm{ha}^{-1}\right)\end{array}$ & $\begin{array}{l}\text { Total N uptake } \\
\left(\mathrm{kg} \mathrm{ha}^{-1}\right)\end{array}$ & $\begin{array}{c}\text { NUtE } \\
\left(\mathrm{kg} \mathrm{kg}^{-1}\right)\end{array}$ & $\begin{array}{l}\text { NHI } \\
(\%)\end{array}$ \\
\hline \multirow[t]{3}{*}{2008} & \multirow[t]{4}{*}{ Tillage (T) } & CT & $128.78 \pm 12.27$ & $87.671^{\mathrm{ab}} \pm 7.51$ & $216.45^{\mathrm{ab}} \pm 16.82$ & $30.496 \pm 1.63$ & $40.587 \pm 2.19$ \\
\hline & & MBP & $126.62 \pm 11.44$ & $77.800^{\mathrm{b}} \pm 5.88$ & $204.42^{\mathrm{b}} \pm 15.11$ & $29.086 \pm 1.92$ & $38.223 \pm 2.22$ \\
\hline & & $\mathrm{CP}$ & $125.73 \pm 6.82$ & $96.017^{\mathrm{a}} \pm 6.49$ & $221.74^{\mathrm{a}} \pm 11.57$ & $32.772 \pm 1.22$ & $43.264 \pm 1.63$ \\
\hline \multirow[t]{4}{*}{ LSD (0.05) } & & & NS & 12.59 & 12.903 & NS & NS \\
\hline & \multirow[t]{5}{*}{ Nitrogen $(\mathrm{N})$} & $\mathrm{N}_{1}$ & $109.61^{\mathrm{b}} \pm 6.41$ & $76.417^{c} \pm 5.88$ & $186.03^{c} \pm 7.75$ & $32.016 \pm 1.98$ & $41.070 \pm 2.57$ \\
\hline & & $\mathrm{N}_{2}$ & $129.18^{\mathrm{a}} \pm 4.05$ & $87.110^{\mathrm{b}} \pm 5.73$ & $216.29^{\mathrm{b}} \pm 5.22$ & $30.382 \pm 1.55$ & $40.210 \pm 2.03$ \\
\hline & & $\mathrm{N}_{3}$ & $142.33^{\mathrm{a}} \pm 8.31$ & $97.961^{\mathrm{a}} \pm 6.41$ & $240.29^{\mathrm{a}} \pm 7.91$ & $29.956 \pm 1.80$ & $40.794 \pm 2.50$ \\
\hline \multirow[t]{2}{*}{ LSD (0.05) } & & & 13.637 & 7.479 & 10.788 & NS & NS \\
\hline & & $\mathrm{T} \times \mathrm{N}$ & NS & NS & NS & NS & NS \\
\hline \multirow[t]{3}{*}{2009} & \multirow[t]{4}{*}{ Tillage (T) } & CT & $132.47 \pm 7.09$ & $97.71^{\mathrm{a}} \pm 8.21$ & $230.18^{a} \pm 13.08$ & $31.547^{\mathrm{ab}} \pm 1.62$ & $42.337^{\mathrm{a}} \pm 2.07$ \\
\hline & & MBP & $132.49 \pm 5.11$ & $82.42^{\mathrm{b}} \pm 7.35$ & $214.91^{\mathrm{b}} \pm 11.28$ & $28.709^{b} \pm 1.12$ & $38.176^{\mathrm{b}} \pm 1.75$ \\
\hline & & $\mathrm{CP}$ & $129.40 \pm 3.79$ & $101.44^{\mathrm{a}} \pm 6.79$ & $230.84^{\mathrm{a}} \pm 9.08$ & $32.840^{\mathrm{a}} \pm 1.05$ & $43.840^{\mathrm{a}} \pm 1.49$ \\
\hline \multirow[t]{4}{*}{ LSD (0.05) } & & & NS & 10.248 & 7.4771 & 2.8522 & 3.3506 \\
\hline & \multirow[t]{5}{*}{ Nitrogen $(\mathrm{N})$} & $\mathrm{N}_{1}$ & $122.53^{\mathrm{c}} \pm 3.81$ & $82.07^{c} \pm 7.61$ & $204.59^{c} \pm 7.01$ & $30.736 \pm 2.07$ & $39.936 \pm 2.70$ \\
\hline & & $\mathrm{N}_{2}$ & $131.14^{\mathrm{b}} \pm 3.46$ & $93.94^{\mathrm{b}} \pm 5.62$ & $225.08^{\mathrm{b}} \pm 4.69$ & $31.202 \pm 1.52$ & $41.672 \pm 1.92$ \\
\hline & & $\mathrm{N}_{3}$ & $140.69^{\mathrm{a}} \pm 2.16$ & $105.56^{\mathrm{a}} \pm 7.13$ & $246.25^{\mathrm{a}} \pm 6.72$ & $31.158 \pm 1.30$ & $42.744 \pm 1.88$ \\
\hline \multirow[t]{2}{*}{ LSD (0.05) } & & & 5.7339 & 10.343 & 8.8526 & NS & NS \\
\hline & & $\mathrm{T} \times \mathrm{N}$ & NS & NS & NS & NS & NS \\
\hline
\end{tabular}

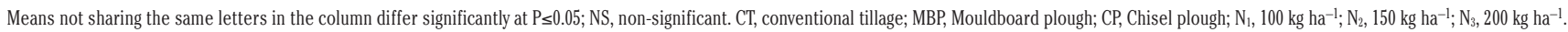




\section{Discussion}

Tillage systems play a significant role to affect the soil bulk density and total porosity, which greatly impact on grain and total $\mathrm{N}$ uptake as well as grain quality in crop plants. In present study, lower soil bulk density and higher total porosity in chisel ploughed plots were recorded which improved the grain and total $\mathrm{N}$ uptake compared with other treatments. Similarly, N application at $200 \mathrm{~kg}$ $\mathrm{ha}^{-1}$ resulted in higher $\mathrm{N}$ uptake as well as maize grain quality compared with other treatments (Tables 1-5 and Figure 2).

Lower bulk density and higher total porosity of soil under chisel plough might be due to ploughing the soil at more depth. As chisel plough disturbed the soil upto $40 \mathrm{~cm}$ depth and helped to reduce bulk density by breaking hard pan. Therefore, deep tilling lowered the soil bulk density by loosening the soil compared with conventional-tillage (Jabro et al., 2010). Higher soil porosity under deep tillage might be due to more pore spaces compared with other tillage systems (Rashidi and Keshavarzpour, 2011). Non-significant effect of tillage systems on soil organic carbon might be due to least difference in organic matter in the soil (Ishaq et al., 2002), as well as due to shorter time period as the effects of tillage system may become clear when studied for longer period. Non-significant but lower soil carbon value might be due to accelerated decomposition of organic matter favoured by strong microbial activities achieved through vigorous soil inversion (Six et al., 2000).

Higher grain and total $\mathrm{N}$ uptake under chisel tilled plots of maize could be due to lower bulk density and higher total porosity of soil (Table 1). Lower bulk density and higher total porosity might have improved root growth and nutrient uptake in maize and also improved soil moisture conservation by loosening the soil through deep tillage (Wang et al., 2015). Another reason may be higher root density and depth for higher $\mathrm{N}$ uptake in maize under chisel plough. In contrast compacted soil with higher soil bulk density reduces root growth (Croser et al., 2000; Lecompte et al., 2003), limits the roots in upper soil layer (Shierlaw and Alston, 1984), and resulted in decreased nutrient and moisture uptake (Watson and Kelsey, 2006) as observed with other tillage systems of present study. Lower oil contents in chisel ploughed treatments
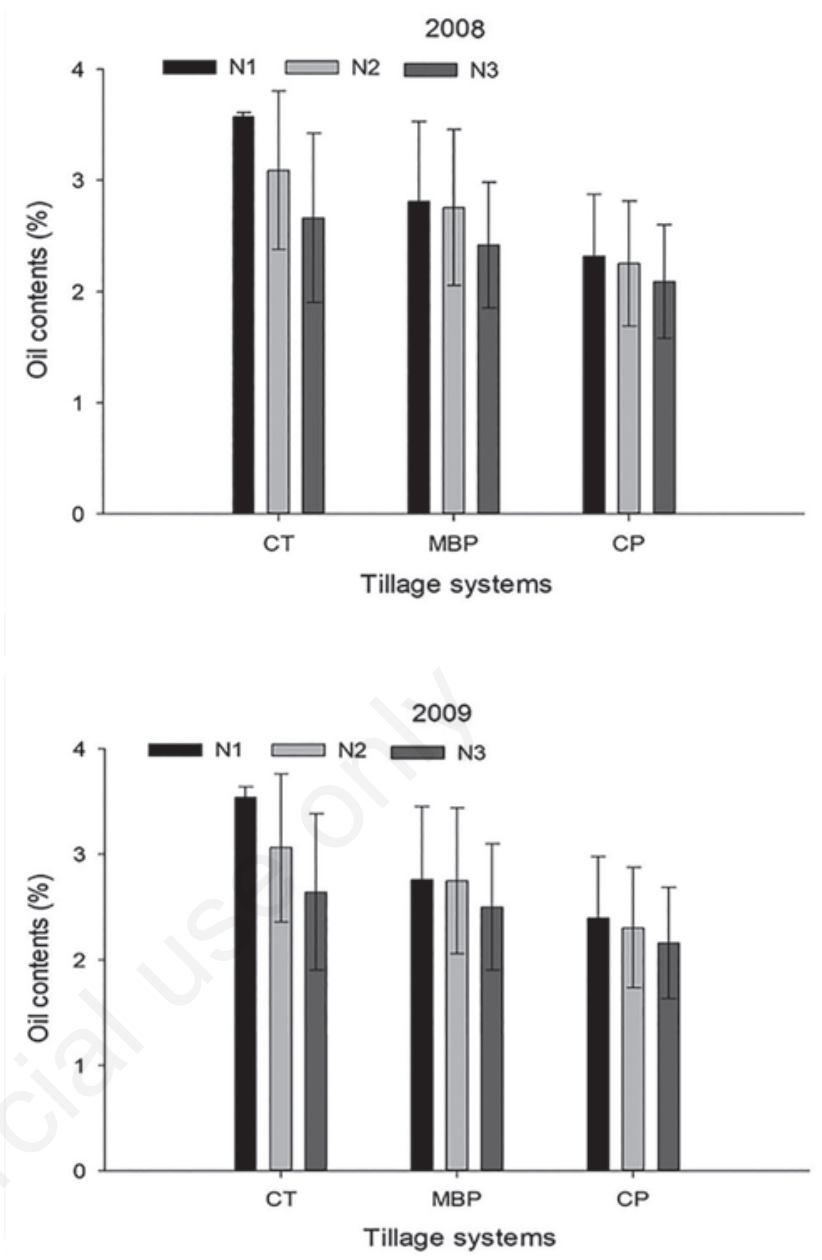

Figure 2. Interaction effect of different tillage systems and nitrogen levels on oil contents (\%) in maize during both study years.

Table 3. Effect of different tillage systems and nitrogen levels on grain quality traits in maize.

\begin{tabular}{|c|c|c|c|c|c|}
\hline Year & & & Protein content (\%) & Oil content (\%) & Starch content (\%) \\
\hline \multirow[t]{3}{*}{2008} & \multirow[t]{4}{*}{ Tillage (T) } & $\mathrm{CT}$ & $8.32 \pm 0.15$ & $3.42^{\mathrm{a}} \pm 0.09$ & $70.63 \pm 0.78$ \\
\hline & & MBP & $8.23 \pm 0.13$ & $3.23^{\mathrm{b}} \pm 0.27$ & $70.67 \pm 0.76$ \\
\hline & & $\mathrm{CP}$ & $8.25 \pm 0.12$ & $2.68^{c} \pm 0.13$ & $70.23 \pm 0.56$ \\
\hline \multirow[t]{4}{*}{$\operatorname{LSD}(0.05)$} & & & NS & 0.11 & NS \\
\hline & \multirow[t]{4}{*}{ Nitrogen $(\mathrm{N})$} & $\mathrm{N}_{1}$ & $8.02^{\mathrm{c}} \pm 0.04$ & $3.42^{\mathrm{a}} \pm 0.25$ & $71.36^{\mathrm{a}} \pm 0.59$ \\
\hline & & $\mathrm{N}_{2}$ & $8.27^{b} \pm 0.04$ & $3.07^{\mathrm{b}} \pm 0.19$ & $70.63^{\mathrm{a}} \pm 0.54$ \\
\hline & & $\mathrm{N}_{3}$ & $8.51^{\mathrm{a}} \pm 0.06$ & $2.83^{c} \pm 0.21$ & $69.55^{\mathrm{b}} \pm 0.53$ \\
\hline LSD (0.05) & & & 0.07 & 0.12 & 0.90 \\
\hline \multirow[t]{3}{*}{2009} & \multirow[t]{4}{*}{ Tillage (T) } & CT & $8.39 \pm 0.14$ & $3.39 \mathrm{a} \pm 0.11$ & $71.19 \pm 0.81$ \\
\hline & & MBP & $8.31 \pm 0.12$ & $3.27^{\mathrm{b}} \pm 0.19$ & $70.78 \pm 1.00$ \\
\hline & & $\mathrm{CP}$ & $8.34 \pm 0.11$ & $2.76^{\mathrm{c}} \pm 0.10$ & $70.56 \pm 0.95$ \\
\hline \multirow[t]{4}{*}{ LSD (0.05) } & & & NS & 0.11 & NS \\
\hline & \multirow[t]{3}{*}{ Nitrogen $(\mathrm{N})$} & $\mathrm{N}_{1}$ & $8.12^{c} \pm 0.06$ & $3.39^{\mathrm{a}} \pm 0.21$ & $72.03^{a} \pm 0.59$ \\
\hline & & $\mathrm{N}_{2}$ & $8.35^{\mathrm{b}} \pm 0.05$ & $3.11^{\mathrm{b}} \pm 0.17$ & $71.18^{\mathrm{a}} \pm 0.54$ \\
\hline & & $\mathrm{N}_{3}$ & $8.57^{\mathrm{a}} \pm 0.05$ & $2.92^{c} \pm 0.17$ & $69.32^{\mathrm{b}} \pm 0.74$ \\
\hline \multirow[t]{2}{*}{ LSD (0.05) } & & & 0.09 & 0.11 & 1.05 \\
\hline & & $\mathrm{T} \times \mathrm{N}$ & NS & $*$ & NS \\
\hline
\end{tabular}

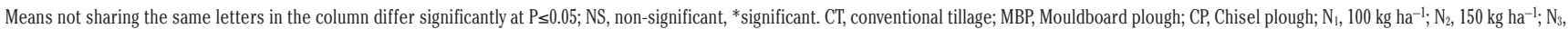
$200 \mathrm{~kg} \mathrm{ha}^{-1}$. 
might be due to higher $\mathrm{N}$ uptake that reduces oil contents in crop plants including maize (Miao et al., 2006) and brassica species (Gupta et al., 2011). The non-significant effect of tillage systems on grain protein contents was also reported by Sabo et al. (2007). A non-significant interaction effect of tillage and nitrogen fertilizer for sugar beet production and quality was also observed by Palumbo et al. (2014).

Different $\mathrm{N}$ levels had non-significant effect on soil properties such as bulk density, total porosity and organic carbon in this study (Table 1). Non-significant effect of $\mathrm{N}$ levels on soil properties such as bulk density; total porosity and organic carbon had been also reported by Hossain et al. (2004). However, higher stover, grain and total $\mathrm{N}$ uptake during both years of study at higher $\mathrm{N}$ level might be due to more availability of $\mathrm{N}$ for plant uptake (Hussaini et al., 2008).

Nitrogen plays significant role in improving protein contents due to presence of amino group, the building blocks for proteins. Higher protein contents at higher $\mathrm{N}$ level of present study might be due to more $\mathrm{N}$ uptake by maize grain compared with other $\mathrm{N}$ levels (Thomison et al., 2004; Rafiq et al., 2010). It is well established that increasing $\mathrm{N}$ supply improves protein contents in cereals grain (Spiertz and Ellen, 1978). With increase in $\mathrm{N}$ rate, the grain protein contents increased, while the starch content decreased (Miao et al., 2006; Zhang et al., 2010). Different $\mathrm{N}$ application rates had negative impact on oil contents and increase in $\mathrm{N}$ rate resulted in reduction of oil contents in maize grain. An adverse effect of $\mathrm{N}$ application on grain starch contents was recorded and increase in $\mathrm{N}$ rate resulted in decline of grain starch contents of present study (Table 3; Miao et al., 2006). Likewise, reduction in maize starch contents by applying more $\mathrm{N}$ was also observed by several researchers (Singh et al., 2004; Zhang et al., 2010).

\section{Conclusions}

Tillage methods had significant impact on soil bulk density, soil porosity, and grain and total $\mathrm{N}$ uptake while non-significant impact on soil organic carbon and grain quality. Lesser soil bulk density and higher soil porosity was achieved through chiseling which resulted in higher N uptake. Similarly, N application resulted in enhanced $\mathrm{N}$ uptake and had significant impact on grain quality. Grain protein contents increased with increasing N levels while grain oil and starch contents were adversely affected by increasing $\mathrm{N}$ levels. Interaction effect of tillage and nitrogen levels was found

Table 4. Interaction effect of different tillage systems and nitrogen levels on soil properties, nitrogen indices and grain quality in maize during 2008.

\begin{tabular}{|c|c|c|c|c|c|c|c|c|c|c|c|}
\hline Treatments & & $\begin{array}{c}\text { Soil } \\
\text { bulk density } \\
\left(\mathrm{Mg} \mathrm{m}^{-3}\right)\end{array}$ & $\begin{array}{l}\text { Soil } \\
\text { porosity } \\
\left(\mathrm{m}^{3} \mathrm{~m}^{-3}\right)\end{array}$ & $\begin{array}{l}\text { Soil C } \\
\text { uptake } \\
\left(\mathrm{g} \mathrm{kg}^{-1}\right)\end{array}$ & $\begin{array}{l}\text { Stover } \mathbf{N} \\
\text { uptake } \\
\left(\mathrm{kg} \mathrm{ha}^{-1}\right)\end{array}$ & $\begin{array}{c}\text { Grain N } \\
\text { uptake } \\
\left(\mathrm{kg} \mathrm{ha}^{-1}\right)\end{array}$ & $\begin{array}{l}\text { Total N } \\
\text { uptake } \\
\left(\mathrm{kg} \mathrm{ha}^{-1}\right)\end{array}$ & $\begin{array}{c}\text { NUtE } \\
\left(\mathrm{kg} \mathrm{kg}^{-1}\right)\end{array}$ & $\begin{array}{l}\text { NHI } \\
(\%)\end{array}$ & $\begin{array}{l}\text { Protein } \\
\text { content } \\
(\%)\end{array}$ & $\begin{array}{l}\text { Starch } \\
\text { content } \\
(\%)\end{array}$ \\
\hline $\begin{array}{l}\text { Tillage } \\
\text { systems }\end{array}$ & $\begin{array}{l}\text { Nitrogen } \\
\text { levels }\end{array}$ & & & & & & & & & & \\
\hline CT & $\begin{array}{l}\mathrm{N}_{1} \\
\mathrm{~N}_{2} \\
\mathrm{~N}_{3}\end{array}$ & $\begin{array}{l}1.47 \\
1.45 \\
1.45\end{array}$ & $\begin{array}{l}0.44 \\
0.45 \\
0.45\end{array}$ & $\begin{array}{c}3.13 \\
3.093 \\
3.25\end{array}$ & $\begin{array}{l}106.21 \\
125.99 \\
137.25\end{array}$ & $\begin{array}{c}72.51 \\
93.50 \\
101.44\end{array}$ & $\begin{array}{l}178.72 \\
219.50 \\
238.69\end{array}$ & $\begin{array}{c}32.00 \\
32.187 \\
31.307\end{array}$ & $\begin{array}{c}40.81 \\
42.55 \\
42.517\end{array}$ & $\begin{array}{c}8.036 \\
8.33 \\
8.59\end{array}$ & $\begin{array}{c}71.49 \\
70.647 \\
69.767\end{array}$ \\
\hline MBP & $\begin{array}{l}\mathrm{N}_{1} \\
\mathrm{~N}_{2} \\
\mathrm{~N}_{3}\end{array}$ & $\begin{array}{c}1.466 \\
1.49 \\
1.506\end{array}$ & $\begin{array}{c}0.446 \\
0.44 \\
0.43 \\
\end{array}$ & $\begin{array}{l}2.80 \\
2.92 \\
3.17\end{array}$ & $\begin{array}{l}108.75 \\
126.51 \\
151.23\end{array}$ & $\begin{array}{l}79.84 \\
83.84 \\
92.67\end{array}$ & $\begin{array}{l}188.60 \\
210.35 \\
243.91\end{array}$ & $\begin{array}{c}32.797 \\
30.04 \\
28.010 \\
\end{array}$ & $\begin{array}{c}42.15 \\
39.737 \\
37.95\end{array}$ & $\begin{array}{c}7.97 \\
8.256 \\
8.45 \\
\end{array}$ & $\begin{array}{c}71.58 \\
71.04 \\
69.397\end{array}$ \\
\hline $\mathrm{CP}$ & $\begin{array}{l}\mathrm{N}_{1} \\
\mathrm{~N}_{2} \\
\mathrm{~N}_{3}\end{array}$ & $\begin{array}{l}1.406 \\
1.396 \\
1.42\end{array}$ & $\begin{array}{l}0.47 \\
0.47 \\
0.46\end{array}$ & $\begin{array}{l}3.07 \\
3.15 \\
3.42\end{array}$ & $\begin{array}{l}113.88 \\
135.05 \\
138.50\end{array}$ & $\begin{array}{l}76.89 \\
83.99 \\
99.77\end{array}$ & $\begin{array}{l}190.77 \\
219.04 \\
238.27\end{array}$ & $\begin{array}{l}31.247 \\
28.92 \\
30.55\end{array}$ & $\begin{array}{c}40.247 \\
38.34 \\
41.91\end{array}$ & $\begin{array}{c}8.04 \\
8.226 \\
8.486\end{array}$ & $\begin{array}{c}71.017 \\
70.19 \\
69.477\end{array}$ \\
\hline LSD & & NS & NS & NS & NS & NS & NS & NS & NS & NS & NS \\
\hline
\end{tabular}

NS, non-significant; CT, conventional tillage; MBP, Mouldboard plough; CP, Chisel plough; $\mathrm{N}_{\mathrm{l}}, 100 \mathrm{~kg} \mathrm{ha}^{-1} ; \mathrm{N}_{2}, 150 \mathrm{~kg} \mathrm{ha}^{-1} ; \mathrm{N}_{3}, 200 \mathrm{~kg} \mathrm{ha}^{-1}$.

Table 5. Interaction effect of different tillage systems and nitrogen levels on soil properties, nitrogen indices and grain quality in maize during 2009.

\begin{tabular}{|c|c|c|c|c|c|c|c|c|c|c|c|}
\hline \multicolumn{2}{|c|}{ Treatments } & $\begin{array}{c}\text { Soil } \\
\text { bulk density } \\
\left(\mathrm{Mg} \mathrm{m}^{-3}\right)\end{array}$ & $\begin{array}{c}\text { Soil } \\
\text { porosity } \\
\left(\mathrm{m}^{3} \mathrm{~m}^{-3}\right)\end{array}$ & $\begin{array}{c}\text { Soil C } \\
\text { uptake } \\
\left(\mathrm{g} \mathrm{kg}^{-1}\right)\end{array}$ & $\begin{array}{c}\text { Stover N } \\
\text { uptake } \\
\left(\mathrm{kg} \mathrm{ha}^{-1}\right)\end{array}$ & $\begin{array}{c}\text { Grain N } \\
\text { uptake } \\
\left(\mathrm{kg} \mathrm{ha}^{-1}\right)\end{array}$ & $\begin{array}{l}\text { Total N } \\
\text { uptake } \\
\left(\mathrm{kg} \mathrm{ha}^{-1}\right)\end{array}$ & $\begin{array}{c}\text { NUtE } \\
\left(\mathrm{kg} \mathrm{kg}^{-1}\right)\end{array}$ & $\begin{array}{l}\text { NHI } \\
(\%) \\
\end{array}$ & $\begin{array}{l}\text { Protein } \\
\text { content } \\
(\%)\end{array}$ & $\begin{array}{l}\text { Starch } \\
\text { content } \\
(\%)\end{array}$ \\
\hline $\begin{array}{l}\text { Tillage } \\
\text { systems }\end{array}$ & $\begin{array}{c}\text { Nitrogen } \\
\text { levels }\end{array}$ & & & & & & & & & & \\
\hline \multirow[t]{3}{*}{ CT } & $\mathrm{N}_{1}$ & 1.46 & 0.45 & 2.88 & 120.25 & 84.77 & 205.02 & 31.777 & 41.277 & 8.126 & 72.157 \\
\hline & $\mathrm{N}_{2}$ & 1.43 & 0.46 & 2.72 & 133.03 & 96.94 & 229.97 & 31.40 & 42.147 & 8.39 & 71.31 \\
\hline & $\mathrm{N}_{3}$ & 1.436 & 0.46 & 2.84 & 144.12 & 111.41 & 255.53 & 31.46 & 43.587 & 8.66 & 70.10 \\
\hline \multirow[t]{3}{*}{ MBP } & $\mathrm{N}_{1}$ & 1.436 & 0.46 & 2.65 & 122.16 & 70.96 & 193.11 & 28.387 & 36.61 & 8.0567 & 72.25 \\
\hline & $\mathrm{N}_{2}$ & 1.47 & 0.44 & 2.84 & 133.94 & 83.76 & 217.70 & 28.74 & 38.44 & 8.356 & 71.37 \\
\hline & $\mathrm{N}_{3}$ & 1.48 & 0.44 & 2.82 & 141.38 & 92.53 & 233.91 & 28.997 & 39.47 & 8.506 & 68.73 \\
\hline \multirow[t]{3}{*}{$\mathrm{CP}$} & $\mathrm{N}_{1}$ & 1.38 & 0.48 & 2.92 & 125.17 & 90.47 & 215.64 & 32.04 & 41.92 & 8.176 & 71.683 \\
\hline & $\mathrm{N}_{2}$ & 1.37 & 0.48 & 3.016 & 126.46 & 101.12 & 227.58 & 33.46 & 44.427 & 8.30 & 70.86 \\
\hline & $\mathrm{N}_{3}$ & 1.41 & 0.47 & 3.076 & 136.58 & 112.73 & 249.31 & 33.01 & 45.173 & 8.55 & 69.14 \\
\hline \multicolumn{2}{|l|}{ LSD } & NS & NS & NS & NS & NS & NS & NS & NS & NS & NS \\
\hline
\end{tabular}

NS, non-significant; CT, conventional tillage; MBP, Mouldboard plough; CP, Chisel plough; $\mathrm{N}_{\mathrm{l}}, 100 \mathrm{~kg} \mathrm{ha}^{-1} ; \mathrm{N}_{2}, 150 \mathrm{~kg} \mathrm{ha}^{-1} ; \mathrm{N}_{3}, 200 \mathrm{~kg} \mathrm{ha}^{-1}$. 
significant only for oil contents, while remained unaffected for all other studied traits. It is therefore, concluded that maize should be grown by ploughing soil with chisel plough to increase soil porosity which increases crop root proliferation and ultimately enhances $\mathrm{N}$ uptake.

\section{References}

Ahmad I, Iqbal M, Ahmad B, Ahmad G, Shah NH, 2009. Maize yield, plant tissue and residual soil $\mathrm{N}$ as affected by nitrogen management and tillage systems. J. Agric. Biol. Sci 1:19-29.

Amanullah, Marwat KB, Shah P, Maula N, Arifullah S, 2009. Nitrogen levels and its time of application influence leaf area, height and biomass of maize planted at low and high density. Pak. J. Bot. 41:761-8.

Anonymous, 1990. Official Methods of Analysis of the Association of Official analytical chemists. 15th ed. Vol. 11. In: K. Helrich (Ed.). Assoc. Off. Ana. Chemists. Inc., Virginia, USA.

Blake GR, Hartge KH, 1986. Bulk density. Pages 363-375 in A. Klute, Ed. Methods of Soil Analysis, Part 1, Agronomy No. 9., 2nd ed. ASA., Madison, WI, USA.

Croser C, Bengough AG, Pritchard J, 2000. The effect of mechanical impedance on root growth in pea (Pisum sativum L.). II. Cell expansion and wall rheology during recovery. Physiol. Plant. 109:150-9.

Daniells IG, 2012. Hardsetting soils: A review. Soil Res. 50: 349-59.

Dinnes DL, Karlen DL, Jaynes DB, Kaspar TC, Hatfield JL, Colvin TS, Cambardella C A, 2002. Nitrogen management strategies to reduce nitrate leaching in tile-drained Midwestern soils. Agron. J. 94:153-71.

Drewry JJ, Lowe JAH, Paton RJ, 2000. Effect of subsoiling on soil physical properties and pasture production on a Pallic soil in Southland, New Zealand. N. Z. J. Agric. Res. 43:269-77.

Feng Y, Ning T, Li Z, Han B, Han H, Li Y, Sun T, Zhang X, 2014. Effects of tillage practices and rate of nitrogen fertilization on crop yield and soil carbon and nitrogen. Plant Soil Environ. 60:100-4.

Freed RD, Scott DE, 1986. MSTAT-C. Crop and Soil Sci. Dept., Michigan State University, Michigan, USA.

Greef JM, Ott H, Wulfes R, Taube F, 1999. Growth analysis of dry matter accumulation and $\mathrm{N}$ uptake of forage maize cultivars affected by N supply. J. Agri. Sci. 132:31-43.

Gupta V, Bhadauria VPS, Agarwal RL, 2011. Effect of nitrogen and split doses of potassium on quality aspects of Brassica species. Afr. J. Agric. Res. 6:285-8.

Hamza, MA, Anderson WK, 2005. Soil compaction in cropping systems: a review of the nature, causes and possible solutions. Soil Till. Res. 82:121-45.

Hossain MF, Akhter MS, Majumder UK, Sikder MSI, Chowdhury MMAA, 2004. Effect of tillage practices and nitrogen levels on the physical properties of soil. Pak. J. Biol. Sci. 7:1876-9.

Hussaini MA, Ogunlela VB, Ramalan AA, Falaki AM, 2008. Mineral composition of dry season maize (Zea mays L.) in response to varying levels of nitrogen, phosphorus and irrigation at Kadawa, Nigeria. World J. Agric. Sci. 4:775-80.

Ishaq M, Ibrahim M, Lal R, 2002. Tillage effects on soil properties at different levels of fertilizer application in Punjab, Pakistan. Soil Till. Res. 68:93-9.

Ishaq M, Ibrahim M, Lal R, 2003. Persistence of subsoil compaction effects on soil properties and growth of wheat and cotton in Pakistan. Expl. Agri. 39:341-8.
Jabro JD, Stevens WB, Iversen WM, Evans RG, 2010. Tillage depth effects on soil physical properties, sugarbeet yield and sugarbeet quality. Communic. Soil Sci. Plant Analysis. 41:908-16.

Ji B, Zhao Y, Mu X, Liu K, Li C, 2013. Effects of tillage on soil physical properties and root growth of maize in loam and clay in central China. Plant Soil Environ. 59:295-302.

Lecompte F, Ozier-Lafontaine H, Pagès L, 2003. An analysis of growth rates and directions of growth of primary roots of fieldgrown banana trees in an andisol at three levels of soil compaction. Agronomie. 23:209-18.

Liu H, Crawford M, Carvalhais LC, Dang YP, Dennis PG, Schenk PM, 2016. Strategic tillage on a Grey Vertosol after fifteen years of no-till management had no short-term impact on soil properties and agronomic productivity. Geoderma. 267:146-55.

Low NH, 1990. Food analysis, 417/717. Laboratory manual Dept. of Applied Microbiology and Food Science, Uini. Saskatchewan, Canada, pp. 37-38.

Mead JA, Chan KJ, 1988. Effect of deep tillage and seedbed preparation on the growth and yield of wheat on a hard-setting soil. Aust. J. Exp. Agric. 28:491-8.

Mensah DK, Al-Kaisi M, 2006. Tillage and nitrogen source and rate effects on corn response in Corn-Soybean Rotation. Agron. J. 98:507-13.

Miao Y, Mulla DJ, Robert PC, Hernandez JA, 2006. Within field variation in corn yield and grain quality responses to $\mathrm{N}$ fertilization and hybrid selection. Agron. J. 98:129-40.

Nagy J, 1997. The effect of fertilization on the yield of maize (Zea mays L.) with and without irrigation. Cereal Res. Communic. 25:69-76.

Oscar RV, Tollenaar M, 2006. Effect of genotype, nitrogen, plant density and row spacing on the area per leaf profile in maize. Agron. J. 98:94-9.

Palumbo AD, Vonella AV, Garofalo P, D'Andrea L, Rinaldi M, 2014. Response of a two-year sugar beet-sweet sorghum rotation to an agronomic management approach diversified by soil tillage and nitrogen fertilization. Ital. J. Agron. 9:109-14.

Rafiq MA, Ali A, Malik MA, Hussain M, 2010. Effect of fertilizer levels and plant densities on yield and protein contents of autumn planted maize. Pak. J. Agri. Sci. 47:201-8.

Rashidi M, Keshavarzpour F, 2011. Effect of different tillage methods on some physical and mechanical properties of soil in the arid lands of Iran. World Appl. Sci. J. 14:1555-8.

Sabo M, Jug D, Jug I, 2007. Effect of reduced tillage on quality traits of soybean (Glycine max L. Merr). Acta Agron. Hungar. 55:83-8.

Schmidt CP, Belford RK, Tennant D, 1994. Effect of different direct drilling and conventional sowing techniques on soil strength, root growth and grain yield of wheat on sand plain soils in Western Australia. Aust. J. Agric. Res. 45:547-64.

Shahzad M, Farooq M, Jabran K, Hussain M, 2016a. Impact of different crop rotations and tillage systems on weed infestation and productivity of bread wheat. Crop Prot. 89:161-9.

Shahzad M, Farooq M, Jabran K, Yasir TA, Hussain M, 2016 b. Influence of various tillage practices on soil physical properties and wheat performance in different wheat-based cropping systems. Int. J. Agri. Biol. 18:821-9.

Sharifi RS, Taghizadeh R, 2009. Response of maize (Zea mays L.) cultivars to different levels of nitrogen fertilizer. J. Food Agri. Env. 7:518-21.

Shierlaw J, Alston AM, 1984. Effect of soil compaction on root growth and uptake of phosphorus. Plant Soil. 77:15-28.

Singh M, Paulsen MR, Tian L, Yao H, 2004. Site-specific study of corn protein, oil, and extractable starch variability using nit 
spectroscopy. Appl. Engin. Agric. 21:239-51.

Six J, Conant EA, Paul EA, Paustian K, 2002. Stabilization mechanisms of soil organic matter: implications for C-saturated soil. Plant Soil 241:155-76.

Spiertz JHJ, Ellen J, 1978. Effects of nitrogen on crop development and grain growth of winter wheat in relation to assimilation and utilization of assimilates and nutrients. Neth. J. Agr. Sci. 25:210-31.

Steel RGD, Torrie JH, Dickey DA, 1997. Principles and Procedures of Statistics. A biometrical approach. McGraw Hill Book Co., New York, USA, pp 400-428.

Thomison PR, Geyer AB, Bishop BL, Young JR, Lentz E, 2004. Nitrogen fertility effects on grain yield, protein, and oil of corn hybrids with enhanced grain quality traits. Crop Manage. 3: doi:10.1094/CM-2004-1124-02-RS.

Vomocil JA, 1965. Porosity. In: Methods of Soil Analysis, Part 1. In: Black C.A. (Ed.), Agronomy Monograph No. 9. American Society of Agronomy, Madison, WI, USA, pp. 300-314.

Wang Y, Chen Y, Rahman S, Froese J, 2009. Tillage effects on soil penetration resistance and early crop growth for Red River clay. Can. Biosyst. Eng. 51.

Wang X, Zhou B, Sun X, Yue Y, Ma W, Zhao M, 2015. Soil tillage management affects maize grain yield by regulating spatial distribution coordination of roots, soil moisture and nitrogen status. PloS One 10:e0129231.

Wasaya A, Tahir M, Ali H, Hussain M, Yasir TA, Sher A, Ijaz M, Sattar A, 2017a. Influence of varying tillage systems and nitrogen application on crop allometry, chlorophyll contents, biomass production and net returns of maize (Zea mays L.). Soil Till. Res. 170:18-26.

Wasaya A, Tahir M, Manaf A, Ahmed M, Kaleem S, Ahmad I, 2011. Improving maize productivity through tillage and nitrogen management. Afr. J. Biotechnol. 10:19025-134.

Wasaya A, Tahir M, Shahzad U, Yasir TA, Aatif HM, Naeem A, 2017b. Response of maize (Zea mays L.) To different tillage regimes and nitrogen timings under semi-arid irrigated condition. Pak. J. Agri. Sci. 54:553-60.

Wasaya A, Tahir M, Tanveer A, Yaseen M, 2012. Response of maize to tillage and nitrogen management. J. Anim. Plant Sci. 22:452-6.

Watson GW, Kelsey P, 2006. The impact of soil compaction on soil aeration and fine root density of Quercus palustris. Urban For Urban Green 4:69-74.

Zhang HL, Wang Q, Zhao YL, Yang QH, Li CH, 2010. Effects of nitrogen fertilization rate and harvest time on summer maize grain yield and its quality. Ying Yong Sheng Tai Xue Bao. 21:2565-72. 